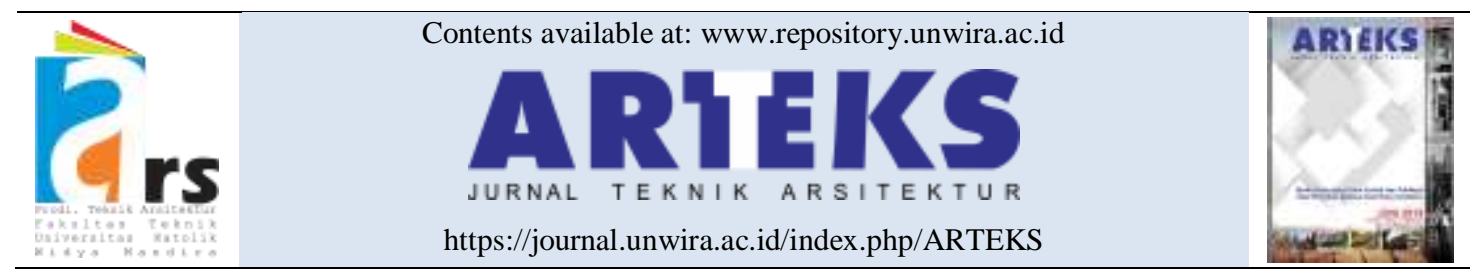

Research paper

doi: $10.30822 /$ arteks.v6i3.877

\title{
An evaluation of shading device in tropics utilising the sun-path diagram
}

\author{
Case study: Banda Aceh Latitude
}

Laina Hilma Sari* ${ }^{\mathbb{D}}$, Era Nopera Rauzi

Department of Architecture, Faculty of Engineering, Universitas Syiah Kuala Jl. Syech Abdurrauf, Darussalam, Banda Aceh, Indonesia

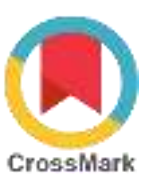

\begin{tabular}{|c|c|}
\hline ARTICLE INFO & ABSTRACT \\
\hline $\begin{array}{l}\text { Article history: } \\
\text { Received January } 07,2021 \\
\text { Received in revised form Feb. } 082021 \\
\text { Accepted September } 11,2021 \\
\text { Available online December } 01,2021\end{array}$ & $\begin{array}{l}\text { Sun orientation plays a significant role in architectural design. } \\
\text { Concerning this, the sun-path diagram is a tool for developing more } \\
\text { knowledge to improve the quality of building design. For achieving } \\
\text { good and thermally comfortable building design, the sun shading } \\
\text { device is essential to work. Therefore, this study performs an }\end{array}$ \\
\hline $\begin{array}{l}\text { *Corresponding author: Laina Hilma Sari } \\
\text { Department of Architecture, Faculty of } \\
\text { Engineering, Univesitas Syah Kuala, } \\
\text { Indonesia } \\
\text { Email: laina_hilma@unsyiah.ac.id } \\
\text { ORCID: https://orcid.org/0000-0002-8163- } \\
\text { 072X }\end{array}$ & $\begin{array}{l}\text { evaluation of the shading device in tropics utilising the sun-path } \\
\text { diagram. This study evaluates the horizontal, vertical and louvre } \\
\text { shadings on eight wind directions in Banda Aceh as a case study in } \\
\text { tropics by adopting shadow angle protractor for superimposing the } \\
\text { vertical (VSA) and horizontal shading angle (HSA) on the } \\
\text { stereographic sun-path diagram to indicate the shadow and } \\
\text { daylighting time. The result of this study proposes the suitable type } \\
\text { of shading and the acceptable depth of horizontal shading } \\
\text { dimensions for all of the orientations of the wind directions. }\end{array}$ \\
\hline
\end{tabular}

\section{Introduction}

Sun orientation plays a significant role in architectural design (Sala and Carta 2014; Kheiri 2018). In architecture, an architect should be familiar with the sun analysis before justifying the form of the building (Behling 1996; Priatman 2000). As the source of heat energy, the sun position on various latitudes would contribute to heating, which can be too excessive that should be minimized by the use of shades or vice versa (Hendricks 2013; Plante 2014). Without understanding this matter, a building would not be a thermally comfortable space. Nowadays, architectural design considering sun latitude is essential because $80 \%$ of energy performance on the building is affected by the early stage of the architectural design (Horvat and Dubois 2012). Concerning sustainability, architects globally have started to minimize the amount of energy that new buildings use (Feist, Pfluger, and Hasper 2020; Halloran et al. 2021). The architects should understand how to reduce the energy use in buildings either for cooling, heating, ventilation, or lighting (Zazzini, Montelpare, and Basti 2018). In this issue, understanding sun path works effectively, which also encompasses ideas of light and passive approaches (Baldwin 2020; Ohki et al. 2019). Even in high rise building shading device plays a very essential effort in saving the energy use of the building (Cho, Yoo, and Kim 2014).

In relation to this matter, sun path diagram would help the architect to design the window and 
shading, which will perform optimal shading design as well as excellent daylighting without excessive heat (Lippsmier 1997; Ardiyanto, Hamid, and Sutopo 2019). A window with too large depth of shading will reject the heat, but in the same time it will use large of lighting energy (Kim et al. 2017). Sun path diagram can determine the horizontal and vertical shadow angles for any specific times. It can also resolve the duration of the sun's irradiation in a facade with an arbitrary direction of the sun. For the building already designed with full window and shade, sun path diagram is able to evaluate the shade over the sunlit area (Prowler 2016). In Architectural Graphic Standards various shading devices are evaluated for temperate climate. It confirmed that both horizontal panel and louvre are well oriented to the south, east and west. While vertical panel, fin and egg-crate are useful for shading the east and west sides (Hoke Jr. and Ramsey 2000). In the tropics, north becomes similar to south, and at the equator they are equal. However, in many cases on the field, the recommended shading devices proposed by Hoke Jr. and Ramsey (2000) do not meet the comfortable criteria (Lechner 2014). In hot humid countries, there are some shading studies conducted. In Egypt, the Horizontal Protruding Ribs has succeeded in reducing the outer surface temperature (Shahda 2020). The research in Malaysia utilizing BIM simulation found that the egg-crate shading device is the best solution in hot humid zone (Shahdan, Ahmad, and Hussin 2018). In Dhaka, Bangladesh, eggcrate type shading also has a better condition of day light provision (Jinia, Trisha, and Mahmood 2015). In Indonesia especially in Aceh, there have not been any studies on this topic. Eventhough Banda Aceh has the same range of latitude as Malaysia, yet, the slightly different latitude will bring different shading dimension working appropriate to the latitude. Therefore, in this study, by working on Banda Aceh latitude as also the representative of tropical latitude, the author evaluated some typical shading devices to various sun orientations utilising the sun path diagram. The novelty of this work is the type and dimension of shading recommended considering the latitude of Banda Aceh city which has not been studied before. The appropriate shading toward the sun orientation would perform well the saving energy- building in tropics which is in this case the latitude of Banda Aceh is the lesson learnt.
Sun path diagram

Sun path related to buildings has been previously well-known studied by Szokolay (2007), who worked with the northern hemisphere and Noebert Lechner (2014) on the southern hemisphere. Sun path diagrams are designed following the scale of altitude circles. Figure 1 shows the sun path diagram, which is commonly appeared as a stereographic diagram. It has azimuthal, altitude, date and month, and hour lines (Sriram 2015). Azimuthal lines are angles running around the edge of the diagram in $15^{\circ}$ increments. The azimuth point is counted from the assigned plot and read from the true north in a clockwise way on the horizontal plane. On the stereographic diagram, the true North is the positive $\mathrm{Y}$-axis (straight up) and is marked with an $\mathrm{N}$.

While altitude lines are the concentric circular dotted lines counted from from the centre of the diagram out, in $10^{\circ}$ increments from $90^{\circ}$ to $0^{\circ}$. The altitude point is counted from the assigned plot on the horizontal plane up. While, Date and month lines perform the sun track over the sky on one precise period within a year. The lines run from the east to the west side which indicate the first day of the month. The hour Lines indicate the sun position on each day, throughout the year (Sriram 2015; McWatters and Haberl 1995).

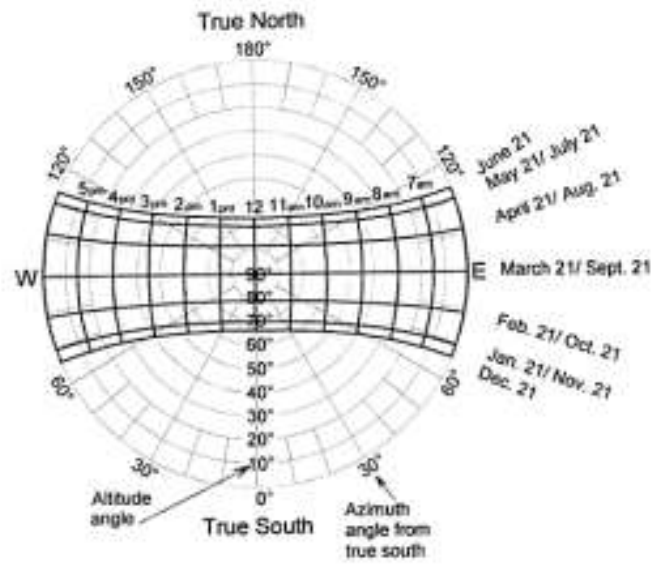

Figure 1. Stereographic sun path diagram of $0^{\circ}$ latitude

\section{Shading}

Working with this kind of sun path diagram, the research would understand to allocate the appropriate external shading device on the buildings for minimizing the heat and glare access during the day (Olgyay and Olgyay 1957; 
Mohammed and Alibaba 2018; Kirimtat et al. 2016). In running this objective, a shadow angle protector and the sun path diagram are utilized. A shadow angle protector is a semi-circular protractor. It has a Horizontal shading angle (HSA) which is shown by radial lines running from $-90^{\circ}$ on the left to $+90^{\circ}$ on the right. This angle protector also has a vertical shading angle (VSA) performed by the arcual lines which coincide with the altitude circles along the centreline (figure 2).
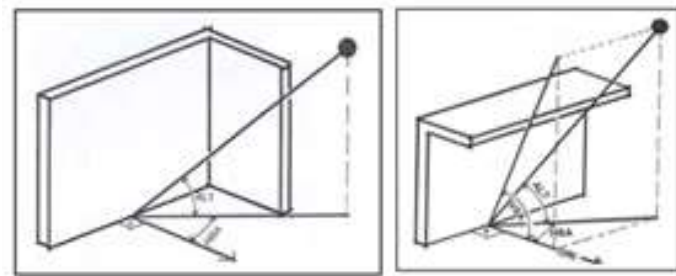

Figure 2. Shading angle (HSA and VSA)

A vertical shading would create Horizontal Shading Angle (HSA), while a horizontal shading would create Vertical Shading Angle (VSA). These identified HSA and VSA angles are further superimposed on the stereographic sun chart (figure 4).

\section{Method}

The study conducts quantitative research. It calculates the shadow angles based on Banda Aceh latitude which is located in the tropical zone, i.e. $5.5483^{\circ} \mathrm{N}, 95.3238^{\circ} \mathrm{E}$. In this case, three simple shading models are evaluated, they are horizontal, vertical and louvre shadings (figure 3 ). The shades are located on eight various wind directions. Each shading has the same dimension, i.e. $1 \mathrm{~m}$ deep for the horizontal one and $1 \mathrm{~m}$ high for the vertical one. The louvre type has $0.70 \mathrm{~m}$ wide. The aim of this study is to indicate which of these shading types that would contribute better shading for Banda Aceh case.

Initially, HSA and VSA of those shadings must be indicated. Further, HSA and VSA are superimposed on the orthographic sun path diagram of Banda Aceh latitude (figure 4). After obtaining shadow times, their eligibilities for optimal shading are evaluated by determining the overheated period. Koga indicated that the high diffuse illuminance (ES) hours in tropics are from 10 am to 4 pm (table 1) (Koga et al. 1993). It also determines the same overheated hours during the day in the tropics. So, in this article, the study evaluates whether the shading device works well to shade during those hours.

Table 1. Diffuse illuminance (ES)

\begin{tabular}{lll}
\hline Sun altitude & Hours & Es $(\mathbf{l x})$ \\
\hline $48-56$ & 10.00 & 23,463 \\
\hline $60-66$ & 11.00 & 30,653 \\
\hline $66-72$ & 12.00 & 38,908 \\
\hline $72-66$ & 14.00 & 38,677 \\
\hline $60-54$ & 15.00 & 32,145 \\
\hline $42-36$ & 16.00 & 23,138 \\
\hline
\end{tabular}

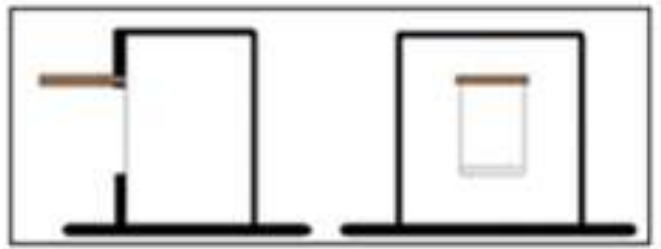

a. Horizontal shading

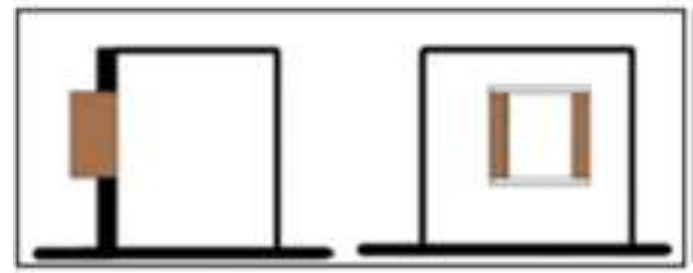

b. Vertical shading

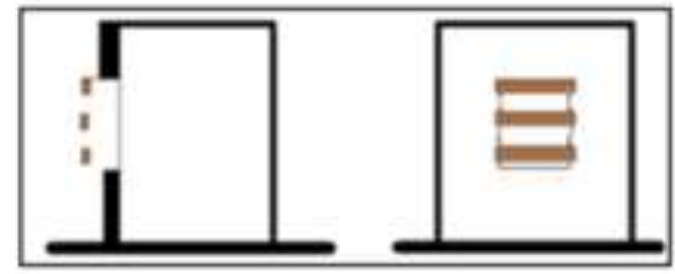

c. Louver

Figure 3. Shading types evaluated in the study 


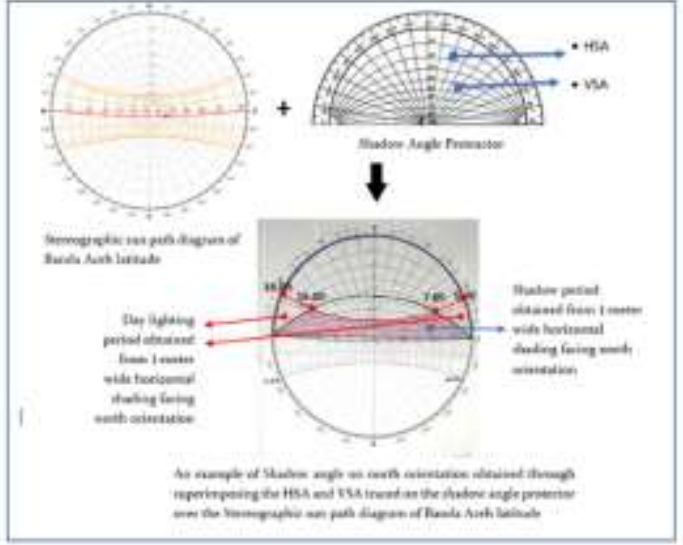

Figure 4. The method of constructing the shadow angles

\section{Result and discussion}

This study demonstrates the eligibility of some shading device based on the latitude of Banda Aceh. The horizontal shading has VSA of 460, and the vertical shading creates 570 of HSA. In comparison, the louvre type creates some VSA angles, namely 150, 520, 570, 730, and 800, respectively (figure 5). As mentioned in the method part, the angles are traced on the shadow angle protector, and further, are superimposed to the stereographic sun path diagram. The position of the shadow angle protractor are to eight wind directions, i.e. North, North- East, East, SouthEast, South, South-West, West and North-West. The result is shown in table 1. Due to the small scale of the picture in table 1 , the daylighting hours are explained through table 2 .
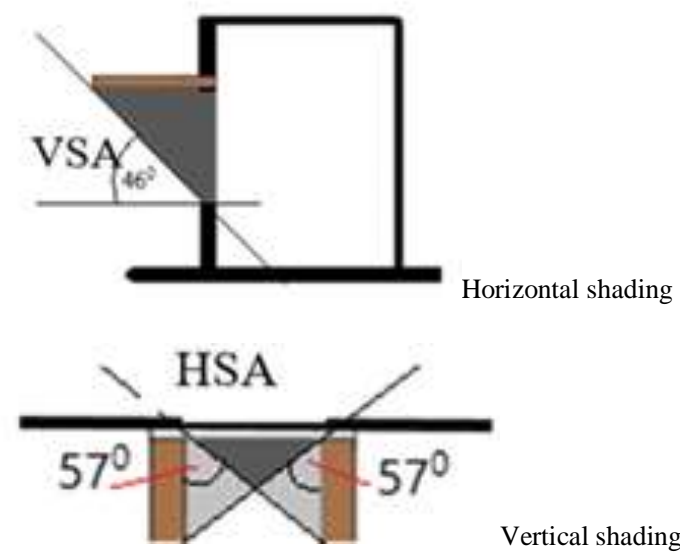

Vertical shading

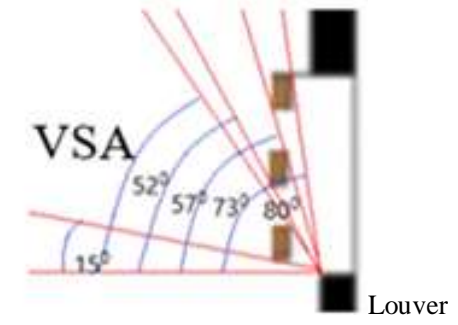

Figure 5. HAS and VSA

North and South orientation

Table 1 and 3 show that on the north orientation, the horizontal shading gives the access of the low daylight, i.e. 05.40 am to 07.05 am during early morning and at $4 \mathrm{pm}$ to $6 \mathrm{pm}$ to light up the room in June 22 nd. The shadow works on the whole day in the entire month of April and May. While on the opposite side, i.e. south orientation, the horizontal shading provides the daylight access on December $22^{\text {nd }}$, from 6 am to 8 am and $3.30 \mathrm{pm}$ to $6 \mathrm{pm}$. It remains the shadow during January, February and March. For North and south orientation, it indicates that horizontal shading is proper to provide shade. However, it looks that 1-meter shading is too long that avoids the daylight for the other months. It also diminishes the good morning sunlight too early, although the excellent morning daylight is before $10 \mathrm{am}$. For Banda Aceh latitude, to provide more sun light up to $10 \mathrm{am}$, the shadow angle protractor points on the higher VSA, i.e. 600 for the northern side and 550 for the southern side. Transforming these angles to Equation 1 (Szokolay 2007) will give the depth of the shade. By giving 1 meter high for the window height, the horizontal shading width is obtained, i.e. $0,57 \mathrm{~m}$ and $0,7 \mathrm{~m}$ respectively for the north and south orientation.

$\operatorname{Tan}(\beta) \mathrm{VSA}=\frac{\text { shading height }}{\text { shading depth }}$

Still, on north orientation, the vertical shading shades the northern part throughout the day except on April, May and June $22^{\text {nd }}$ which have the room lit by the sun around 09.35 are to $2 \mathrm{pm}$. These hours are quite severe for having direct daylight. On the contrast side, i.e. south orientation also performs the same condition where at 8.25 am the vertical shading device keeps forming such phenomenon. Therefore, combining this such shading with another type of shading device or planting some trees for getting the additional shade would perform a better time of shading time. At the same time, the louvre 
shading gives more shadings up to nearly evening. However, due to some leaks on the shading, the unfavourable direct daylight almost runs throughout the day in between April and May; August and September.

\section{North-East and South-West orientation}

For the shading facing North-East orientation, the horizontal shading in this orientation gives plenty of shadows. In this case, the sunray on December $22^{\text {nd }}$ light up the room just about one hour from 6 am to $7 \mathrm{am}$. While on March $22^{\text {nd }}$ and September $23^{\text {rd }}$, the sunlight runs from $05.40 \mathrm{am}$ to 8 am to light up the room. During December $22^{\text {nd }}$ the sun enters the room from 05.40 am to $08.59 \mathrm{am}$. On the opposite side, i.e. South-West, the horizontal shade gives plenty of access for daylight on December in the afternoon from $2 \mathrm{pm}$ $6 \mathrm{pm}$. However, the daylight at $2 \mathrm{pm}-4 \mathrm{pm}$ is not preferable due to the high heat radiation, therefore should be avoided. There is a different recommendation for the two opponent orientations. For the North-East side, the shorter shading device is proposed. From the shadow angle protractor, superimposing the VSA on 600 is able to give more light up to $10 \mathrm{am}$. Working with equation 1 , the shading depth is obtaines i.e. $0,57 \mathrm{~m}$. For the south-West, the longer horizontal shading is needed for avoiding the afternoon lower sunlight. Using equation 1 , to prevent the sunlight up to $4 \mathrm{pm}$, the VSA should be minimized up to 300 . It creates the shading depth up to $1,75 \mathrm{~m}$. However, it is too long for the shading depth. The extended size of shading sometimes is not applicable due to the limited size of the house site. It, therefore, needs additional natural shading such as trees or hanging vegetations instead of lengthening the shading width which requires less space.

Table 2. Result of superimposing VSA and HSA on the shadow angle protractor over Banda Aceh stereographic sun path diagram

Shanding North North-East East South-East South
type.

Another type of shading device, i.e. vertical shading. Table 3 shows that on the north orientation, the vertical shade performs fewer hours of shade which only works more on December $12^{\text {th }}$. During March 3rd, September 9th and June $22^{\text {nd }}$, there are no shades made, which means the severe daylight will dominate from early morning to noon. While on the opposite, i.e. south-west, the vertical shade gives access to the sunlight from around 11.30 am to $6 \mathrm{pm}$. While on June $22^{\text {nd }}$, it remains shaded throughout the day. For louvre type, the shadow almost works on an entire morning to noon. In this case, the jalousie type has some spaces, therefore, creates some short times of sunray direct access, i.e. on December $22^{\text {nd }}$ at 6 am-9.10 am; $7.40 \mathrm{am}-7.55 \mathrm{am}$ and 9 am to $10 \mathrm{am}$. On March $22^{\text {nd }}$ and September $23^{\text {rd }}$, the sunray runs via this opening at $05.50 \mathrm{am}$ -6.40 am; 8.50 am- 9 am and 10.55 am-11.50 am. Vice versa, on the opposite side, i.e. south-west, the louvre gives the same phenomenon yet in the afternoon time. To remedy the vertical and louvre type, we need to combine the shading with natural 
shadings such as bush or trees the same as on the north orientation.

\section{East and West orientation}

Table 2 and 3 indicate that 1-meter long horizontal shading at the east orientation gives the daylight access from early morning to $8.50 \mathrm{am}$. Vice versa, the same shading on the west side provides access at $2.50 \mathrm{pm}$ to $6 \mathrm{pm}$. concerning this, the east orientation needs a shorter shading. In comparison, the west side requires the longer shading for meeting the appropriate daylight duration (Archinotes, 2020). From the shadow angle protractor, the applicable VSA for the east and west orientation are 700 and 250 respectively. Using equation 1 , the shading widths obtained are $0,36 \mathrm{~m}$ for the east side and $2,17 \mathrm{~m}$ for the west. The large size of shade can be represented on a terrace roof for giving more shade to the room. However, if the house site does not allow it, the west orientation can be additionally shaded with vertical vegetation or any similar natural shadings.

The north-facing vertical admits less time of being shaded and extensive period of daylight from morning up to $11.40 \mathrm{am}$. Vice versa, on the west side, it works in the afternoon from noon to nearly evening. The lack of shadow obtained in the room recommend that this kind of shading should be additionally shaded either by adding more fins or being combined with the other type of shading device. The louvre shading on these orientations performs similar shadow period. Therefore, it needs some combinations with the horizontal one.

South-East and North-West orientation

In the south-east and north-west orientations, all of the types of shadings, i.e. horizontal, vertical and louvre shading give a close performance to one of the similar shadings in the North-East and South-West facade. The difference is too little so that the recommendations are also identical. Thus, instead of using $1 \mathrm{~m}$ depth of horizontal shading, the South-East orientation is better shaded with the shading depth of $0,57 \mathrm{~m}$ and $1,75 \mathrm{~m}$.

All the figures resume that the shading device should be well designed based on the period of sunray lighting up the room. The best sunlight will give sufficient light without excessive heat. A large amount of sunlight illuminance (lx) ranges from 10 am to $4 \mathrm{pm}$ (Koga et al. 1993). Yet, this light will contribute to high heat radiation too. Thus, this research initiates the shading device that could pass the sunlight just before 10 am and after $4 \mathrm{pm}$, which also means of providing shade during those hours. For this ability, the highest point, i.e. $\sqrt{ } \sqrt{ }$ is marked on the shading device which means that the shading performs optimum shades.

Table 2 and 3 show that the horizontal shade is perfect in giving shade for north, North-East, East, South-East and South. It confirms the result of the other study that horizontal shading performs well to give a shade (Kim et al. 2017). On this orientation, the horizontal shade is able to provide shade on the peak hours of high radiation of the sun. While in the other direction, there are some of peak hours that the shade cannot avoid the sunray. Table 3 shows that the combination of the jalousie window and horizontal shade will give good hours of shading. Table 3 indicates that the jalousie window is better than the vertical shading yet has some hours where the peak sun rays passing through. The vertical shading has poor performance because of its lack of ability in providing appropriate shades in some months. In this case, the shading device is designed on two sheets of vertical shading. It can be much improved if the vertical shading designs in more layers to give more shade. However, the repetitive vertical shading (fins) would provide some distractions in viewing outside (figure 6).

Table 3. Shading device evaluation

\begin{tabular}{|c|c|c|c|c|c|c|c|}
\hline & \multirow{2}{*}{$\begin{array}{l}\text { Period of } \\
\text { sun path }\end{array}$} & \multicolumn{3}{|c|}{ Period of sun light entering the room } & \multicolumn{3}{|c|}{$\begin{array}{l}\text { Satification on period of shade and } \\
\text { convenient sun light time }\end{array}$} \\
\hline & & $\begin{array}{l}\text { Horizontal } \\
\text { shading }\end{array}$ & $\begin{array}{l}\text { Vertical } \\
\text { shading }\end{array}$ & Louver shading & $\begin{array}{l}\text { Horizontal } \\
\text { shading }\end{array}$ & $\begin{array}{l}\text { Vertical } \\
\text { shading }\end{array}$ & $\begin{array}{l}\text { Jalousie } \\
\text { shading }\end{array}$ \\
\hline North & $\begin{array}{l}\text { March } 22 \\
\text { and Sept. } \\
23\end{array}$ & - & - & - & $\sqrt{ } \sqrt{ }$ & $\sqrt{ }$ & $\sqrt{ } \sqrt{ }$ \\
\hline
\end{tabular}




\begin{tabular}{|c|c|c|c|c|c|c|c|}
\hline & \multirow{2}{*}{$\begin{array}{l}\text { Period of } \\
\text { sun path }\end{array}$} & \multicolumn{3}{|c|}{ Period of sun light entering the room } & \multicolumn{3}{|c|}{$\begin{array}{l}\text { Satification on period of shade and } \\
\text { convenient sun light time }\end{array}$} \\
\hline & & $\begin{array}{l}\text { Horizontal } \\
\text { shading }\end{array}$ & $\begin{array}{l}\text { Vertical } \\
\text { shading }\end{array}$ & Louver shading & $\begin{array}{l}\text { Horizontal } \\
\text { shading }\end{array}$ & $\begin{array}{l}\text { Vertical } \\
\text { shading }\end{array}$ & $\begin{array}{l}\text { Jalousie } \\
\text { shading }\end{array}$ \\
\hline \multirow[t]{3}{*}{$\begin{array}{l}\text { North- } \\
\text { East }\end{array}$} & Dec. 22 & 6am-7am & - & $\begin{array}{l}\text { 6am-6.10am; 7.40am- } \\
\text { 7.55am; 9am-10am }\end{array}$ & \multirow{3}{*}{$\sqrt{ } \sqrt{ }$} & \multirow{3}{*}{$\sqrt{ } \sqrt{ }$} & \multirow{3}{*}{$\sqrt{ } \sqrt{ }$} \\
\hline & $\begin{array}{l}\text { March 22 } \\
\text { and Sept. } \\
23\end{array}$ & $\begin{array}{l}\text { 5.50am- } \\
8 \mathrm{am}\end{array}$ & $\begin{array}{l}5.50 \mathrm{am}- \\
10.20 \mathrm{am}\end{array}$ & $\begin{array}{l}5.50 \mathrm{am}-6.40 \mathrm{am} ; \\
8.50 \mathrm{am}-9 \mathrm{am} ; 10.55 \mathrm{am}- \\
11.50\end{array}$ & & & \\
\hline & June 22 & $\begin{array}{l}5.40 \mathrm{am}- \\
8.59 \mathrm{am}\end{array}$ & $\begin{array}{l}5.40 \mathrm{am}- \\
12 \mathrm{pm}\end{array}$ & $\begin{array}{l}\text { 5.40am-6.50am; } \\
9.30 \mathrm{am}-9.55 \mathrm{am} \\
12.05 \mathrm{pm}-1.05 \mathrm{pm}\end{array}$ & & & \\
\hline \multirow[t]{3}{*}{ East } & Dec. 22 & $\begin{array}{l}\text { 6am- } \\
8.50 \mathrm{am}\end{array}$ & $\begin{array}{l}\text { 6am- } \\
10.20 \mathrm{am}\end{array}$ & $\begin{array}{l}\text { 6am-10.58am; 9.05am- } \\
9.30 \mathrm{am} ; 11 \mathrm{am}-11.50 \mathrm{am}\end{array}$ & \multirow{3}{*}{$\sqrt{ } \sqrt{ }$} & \multirow{3}{*}{$\sqrt{ } \sqrt{ }$} & \multirow{3}{*}{$\sqrt{ } \sqrt{ }$} \\
\hline & $\begin{array}{l}\text { March } 22 \\
\text { and Sept. } \\
23\end{array}$ & $\begin{array}{l}5.50 \mathrm{am}- \\
8.10 \mathrm{am}\end{array}$ & $\begin{array}{l}5.50 \mathrm{am}- \\
11.55 \mathrm{am}\end{array}$ & $\begin{array}{l}\text { 5.50aam-6.45am; } \\
8.55 \mathrm{am}-9.05 \mathrm{am} ; \\
11.05 \mathrm{am}-12.05 \mathrm{pm}\end{array}$ & & & \\
\hline & June 22 & $\begin{array}{l}5.40 \mathrm{am}- \\
7 \mathrm{am}\end{array}$ & & $\begin{array}{l}\text { 5.40am-6am; 7.30am- } \\
\text { 7.50am; 9.30am- } \\
10.05 \mathrm{am}\end{array}$ & & & \\
\hline \multirow[t]{3}{*}{ South } & Dec. 22 & $\begin{array}{l}\text { 6am-8am; } \\
3.30 \mathrm{pm}- \\
6 \mathrm{pm}\end{array}$ & $\begin{array}{l}8.25 \mathrm{am}- \\
3 \mathrm{pm}\end{array}$ & $\begin{array}{l}\text { 6am-6.20am; 8.40am- } \\
9.30 \mathrm{am} ; 2 \mathrm{pm}-2.55 \mathrm{pm} ; \\
5.10 \mathrm{pm}-5.55 \mathrm{pm}\end{array}$ & \multirow{3}{*}{$\sqrt{ } \sqrt{ }$} & \multirow{3}{*}{$\sqrt{ }$} & \multirow{3}{*}{$\sqrt{ } \sqrt{ }$} \\
\hline & $\begin{array}{l}\text { March 22 } \\
\text { and Sept. } \\
23\end{array}$ & & $\begin{array}{l}11.20 \mathrm{am}- \\
12.20 \mathrm{pm}\end{array}$ & $5.50 \mathrm{am}-6 \mathrm{pm}$ & & & \\
\hline & June 22 & & & & & & \\
\hline \multirow[t]{3}{*}{ West } & Dec. 22 & $\begin{array}{l}2.30 \mathrm{pm}- \\
6 \mathrm{pm}\end{array}$ & $\begin{array}{l}12.45 \mathrm{pm}- \\
6 \mathrm{pm}\end{array}$ & $\begin{array}{l}11.50 \mathrm{am}-12.05 \mathrm{pm} ; \\
1.50 \mathrm{pm}-2 \mathrm{pm} ; 4.30 \mathrm{pm}- \\
5.50 \mathrm{pm}\end{array}$ & \multirow{3}{*}{$\sqrt{ }$} & \multirow{3}{*}{$\sqrt{ }$} & \multirow{3}{*}{$\sqrt{ } \sqrt{ }$} \\
\hline & $\begin{array}{l}\text { March } 22 \\
\text { and Sept. } \\
23\end{array}$ & $\begin{array}{l}2.50 \mathrm{pm}- \\
6 \mathrm{pm}\end{array}$ & $\begin{array}{l}12.05 \mathrm{pm}- \\
6 \mathrm{pm}\end{array}$ & $\begin{array}{l}11.50 \mathrm{pm}-12.30 \mathrm{pm} ; 2 \mathrm{pm}- \\
2.20 \mathrm{pm} ; 4.45 \mathrm{pm}-6 \mathrm{pm}\end{array}$ & & & \\
\hline & June 22 & $\begin{array}{l}2.55 \mathrm{pm}- \\
5.50 \mathrm{pm}\end{array}$ & $\begin{array}{l}1 \mathrm{pm}- \\
5.50 \mathrm{pm}\end{array}$ & $\begin{array}{l}11.50 \mathrm{pm}-12.10 \mathrm{pm} ; 1 \mathrm{pm}- \\
1.10 \mathrm{pm} ; 4.50 \mathrm{pm}-6 \mathrm{pm}\end{array}$ & & & \\
\hline \multirow[t]{3}{*}{$\begin{array}{l}\text { North- } \\
\text { West }\end{array}$} & Dec. 22 & $\begin{array}{l}4.10 \mathrm{pm}- \\
5.50 \mathrm{pm}\end{array}$ & & $\begin{array}{l}1.45 \mathrm{pm}-2.20 \mathrm{pm} \\
3.50 \mathrm{pm}-4 \mathrm{pm} ; 12.05 \mathrm{pm}- \\
5.50 \mathrm{pm}\end{array}$ & \multirow{3}{*}{$\sqrt{ } \sqrt{ }$} & \multirow{3}{*}{$\sqrt{ }$} & \multirow{3}{*}{$\sqrt{ } \sqrt{ }$} \\
\hline & $\begin{array}{l}\text { March } 22 \\
\text { and Sept. } \\
23\end{array}$ & $\begin{array}{l}3.40 \mathrm{pm}- \\
6 \mathrm{pm}\end{array}$ & $\begin{array}{l}1.10 \mathrm{pm}- \\
6 \mathrm{pm}\end{array}$ & $\begin{array}{l}12 \mathrm{pm}-12.55 \mathrm{pm} ; 2.50 \mathrm{pm}- \\
3 \mathrm{pm} ; 5 \mathrm{pm}-6 \mathrm{pm}\end{array}$ & & & \\
\hline & June 22 & $\begin{array}{l}2 . .50 \mathrm{pm}- \\
6 \mathrm{pm}\end{array}$ & $\begin{array}{l}11.30 \mathrm{pm}- \\
5.50 \mathrm{pm}\end{array}$ & $\begin{array}{l}10.10 \mathrm{am}-11.30 \mathrm{am} ; \\
11.30 \mathrm{am}-2 \mathrm{pm} ; 4.45 \mathrm{pm}- \\
5.05 \mathrm{pm}\end{array}$ & & & \\
\hline
\end{tabular}

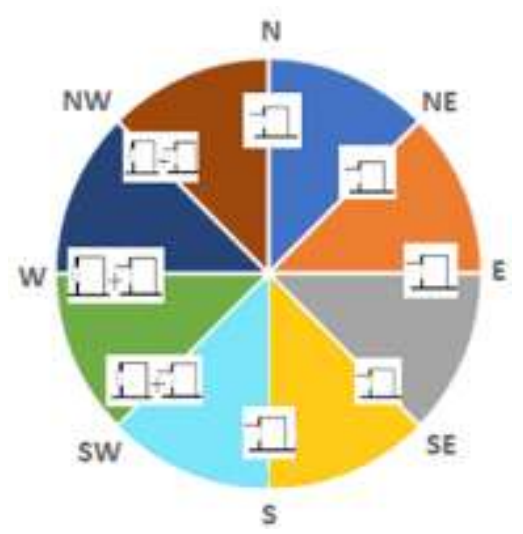

Figure 6. The shading device recommendation on various wind directions in Banda Aceh latitude

\section{Conclusion}

This study evaluates the horizontal, vertical and louvre shadings on eight wind directions in Banda Aceh as a case in tropics. This study performs a different recommendation of sun shading device from the previous theory. In Banda Aceh latitude, i.e. $5.5483^{\circ} \mathrm{N}, 95.3238^{\circ} \mathrm{E}$, horizontal shading works effectively in north, north-east, east, southeast and south. The vertical shading performs slightly poor effect in giving shadow throughout the year in every orientation. It works effectively if added more fins or the vertical panels, yet it distracts the outside view. In contrast, the louvre, combined with short overhang horizontal panel 
shows the best performance in north-west, west and south-west orientations. However, this variation would also diminish the view to outside the same as the vertical one. This study also indicates that the sufficient depths of horizontal shading for north and south orientation are $0,57 \mathrm{~m}$ and $0,7 \mathrm{~m}$ respectively. For East and West orientations, the recommended depth of the horizontal panels is $0,36 \mathrm{~m}$ and $2,17 \mathrm{~m}$, respectively. For north-east and south-east, the shading depth will be sufficient on $0,57 \mathrm{~m}$. While the north-west and south-west orientation, the shading depth works best on $1,75 \mathrm{~m}$.

\section{Acknowledgements}

The authors thank Universitas Syiah Kuala (USK) for funding this research through Lektor research grant 2020.

\section{References}

Ardiyanto, Antonius, N. H. Hamid, and Yeri Sutopo. 2019. 'Thermal Comfort of Colonial Office Building, Semarang Using EnergyPlus Simulation'. ARPN Journal of Engineering and Applied Sciences 14 (4): 834-41. http://www.arpnjournals.org/jeas/research_pa pers/rp_2019/jeas_0219_7623.pdf.

Baldwin, Eric. 2020. 'Solar Design: How Architecture and Energy Come Together'. Archdaily. 2020. https://www.archdaily.com/933697/solardesign-how-architecture-and-energy-cometogether\#: :text=Solar design in contemporary architecture is rooted in the profession's sustainable turn.\&text $=\mathrm{As}$ one way to begin,and architecture around the world.

Behling, Sophia. 1996. Sol Power: The Evolution of Solar Architecture. Munich: Prestel Pub.

Cho, Jinkyun, Changwoo Yoo, and Yundeok Kim. 2014. 'Viability of Exterior Shading Devices for High-Rise Residential Buildings: Case Study for Cooling Energy Saving and Economic Feasibility Analysis'. Energy and Buildings 82 (October): 771-85. https://doi.org/10.1016/j.enbuild.2014.07.092

Feist, Wolfgang, Rainer Pfluger, and Wolfgang Hasper. 2020. 'Durability of Building Fabric
Components and Ventilation Systems in Passive Houses'. Energy Efficiency 13 (8): 1543-59. https://doi.org/10.1007/s12053019-09781-3.

Halloran, John, Elena Gaura, Dan Goldsmith, and Setiadi Yazid. 2021. 'The Meanings of Energy: A Case Study of Student Air Conditioning Activity'. Energy Efficiency 14 (2): 22. https://doi.org/10.1007/s12053-02109934-3.

Hendricks, John. 2013. 'Architecture For Specific Sites 3: Sun Orientation And Control'. Hendricks $\quad 2013$. https://www.hendricksarchitect.com/architect ure/architecture-sites-sun-orientation-control.

Hoke Jr., John Ray, and Charles George Ramsey. 2000. Architectural Graphic Standards. 10th ed. Hoboken, New Jersey: Wiley.

Horvat, Miljana, and Marie-Claude Dubois. 2012. 'Tools and Methods for Solar Design-An Overview of IEA SHC Task 41, Subtask B'. Energy Procedia 30: 1120-30. https://doi.org/10.1016/j.egypro.2012.11.125.

Jinia, Mahbuba Afroz, Syma Haque Trisha, and Taqir Mahmood. 2015. 'Performance of Fixed Shading Devices on Daylight Penetration in the Tropical City Like Dhaka' 2 (3): 21-27. https://www.researchgate.net/publication/331 987698_Performance_of_Fixed_Shading_De vices_on_Daylight_Penetration_in_the_Tropi cal_City_Like_Dhaka.

Kheiri, Farshad. 2018. 'A Review on Optimization Methods Applied in EnergyEfficient Building Geometry and Envelope Design'. Renewable and Sustainable Energy Reviews 92 (September): 897-920. https://doi.org/10.1016/j.rser.2018.04.080.

Kim, Seok-Hyun, Kyung-Ju Shin, Hyo-Jun Kim, and Young-Hum Cho. 2017. 'A Study on the Effectiveness of the Horizontal Shading Device Installation for Passive Control of Buildings in South Korea'. International Journal of Polymer Science 2017: 1-11. https://doi.org/10.1155/2017/3025092.

Kirimtat, Ayca, Basak Kundakci Koyunbaba, Ioannis Chatzikonstantinou, and Sevil Sariyildiz. 2016. 'Review of Simulation Modeling for Shading Devices in Buildings'. Renewable and Sustainable Energy Reviews 53 (January): 23-49. https://doi.org/10.1016/j.rser.2015.08.020.

Koga, Yasuko, Hiroshi Nakamura, M. Ramli Rahim, and Koichi Goto. 1993. 'Daylight Measurement in Indonesia'. Journal of the 
Illuminating Engineering Institute of Japan 77 (Appendix): 60-61. https://doi.org/10.2150/jieij1980.77.Appendi x_60.

Lechner, Norbert M. 2014. Heating, Cooling, Lighting: Sustainable Design Methods for Architects. 4th ed. Hoboken, New Jersey: Wiley.

Lippsmier, George. 1997. Bangunan Tropis. Jakarta: Penerbit Erlangga.

McWatters, K., and J. Haberl. 1995. ‘A Procedure for Plotting the Sun-Path Diagram, and Shading Mask Protector'. Journal of Solar Energy Engineering 117 (2): 153-56. https://doi.org/10.1115/1.2870854.

Mohammed, Khadijah Inna, and Halil Zafer Alibaba. 2018. 'Solar Control and Shading Strategies for Double Skin Facade in Hot Climate'. Imperial Journal of Interdisciplinary Research (IJIR) 4 (1): 20515.

https://www.researchgate.net/publication/322 500377_solar_control_and_shading_strategie s_for_double_skin_facades_in_hot_climate.

Ohki, Chikako, Toshihide Okamoto, Jyurie Tadaki, Tatsuya Yamamoto, Hiroshi Ohga, and Nozomu Yoshizawa. 2019. 'Optimization of Outside and inside Sun Shading Devices Using Radiance and Newhasp'. Journal of Environmental Engineering (Transactions of AIJ) $\quad 84 \quad$ (766): $1067-76$. https://doi.org/10.3130/aije.84.1067.

Olgyay, Aladar, and Victor Olgyay. 1957. Solar Control \& Shading Devices. Princeton, New Jersey: Princeton University Press.

Plante, Russell H. 2014. 'Simple Solar Basics'. In Solar Energy, Photovoltaics, and Domestic Hot Water: A Technical and Economic Guide for Project Planners, Builders, and Property Owners, 1st ed., 230. Cambridge, Massachusetts: Academic Press is an imprint of Elsevier.

Priatman, Jimmy. 2000. 'Perspektif Arsitektur Surya Di Indonesia'. Dimensi 28 (1): 1-7. https://dimensi.petra.ac.id/index.php/ars/artic le/view/15720.

Prowler, Don. 2016. 'Sun Control And Shading Devices'. WBDG: Whole Building Design Guide. 2016. https://www.wbdg.org/resources/sun-controland-shading-devices.

Sala, Marco, and Alessandra Carta. 2014. 'Sustainable Buildings in Mediterranean Area'. In Sustainability, Energy and
Architecture Case Studies in Realizing Green Buildings. United States: Academic Press is an imprint of Elsevier. https://prolightinggroup.com/wpcontent/uploads/2020/08/SustainabilityEnergy-and-Architecture.-Case-Studies-inRealizing-Green-Buildings.pdf.

Shahda, Merhan M. 2020. 'Self-Shading Walls to Improve Environmental Performance in Desert Buildings'. Architecture Research 10 (1): $1-14$. https://doi.org/10.5923/j.arch.20201001.01.

Shahdan, M S, S S Ahmad, and M A Hussin. 2018. 'External Shading Devices for Energy Efficient Building'. IOP Conference Series: Earth and Environmental Science 117 (February): 012034 https://doi.org/10.1088/17551315/117/1/012034.

Sriram, Kompella Kasyapa. 2015. 'Different Forms of Sun-Path Diagrams and Their Uses in Functional Design of Buildings'. Slideshare a Scribd Company. 2015. https://www.slideshare.net/3064026/sunpathdiagrams-different-forms-and-their-uses-infunctional-design.

Szokolay, Steven V. 2007. Solar Geometry. Brisbane, QLD, Australia: PLEA: Passive and Low Energy Architecture International in association with Department of Architecture, The University of Queensland Brisbane. http://www.plea-arch.org/wpcontent/uploads/PLEA-NOTE-1-SOLARGEOMETRY.pdf.

Zazzini, Paolo, Sergio Montelpare, and Antonio Basti. 2018. 'Climate Dependence of Energy Saving Strategies in Public Buildings Characterized by Change of Use: An Original Case Study'. Energy Efficiency 11 (2): 499519. https://doi.org/10.1007/s12053-0179585-5.

\section{Author(s) contribution}

Laina Hilma Sari contributed to the research concepts preparation, methodologies, investigations, data analysis, visualization, articles drafting and revisions.

Era Nopera Rauzi contribute to the research concepts preparation and literature reviews, data analysis, of article drafts preparation and validation. 
ARTEKS : Jurnal Teknik Arsitektur, Volume 6 Issue 3, December 2021

pISSN 2541-0598; eISSN 2541-1217 